\title{
'n Verkennende studie met die oog op die identifisering en kategorisering van leerteorieë met verwysing na die prediking
}

\author{
C M van den Berg \& T F J Dreyer \\ Universiteil van Pretoria
}

\begin{abstract}
An introductory study to identify and classify theories of learning with regard to the task of preaching

Learning is a lifelong process in which man must be what he can be, namely a being interacting with his world in a creative problem-solving manner for the well-being of himself and others. In a similar sense the church has always seen her task in preaching, supported by all the other domains of churchlife, as that of teaching people to come to terms with the gospel of Jesus Christ in their daily existence. This article proposes to identify, categorize and integrate the acknowledged theories underlying the learning process, as they exist in the social sciences, into an allencompassing model for learning; a model from which conclusions are drawn in the hope that further studies can spell out the implications of these conclusions as they are applicable to the task of preaching within the church.
\end{abstract}

\section{INLEIDING}

\subsection{Hipotese}

Die fenomeen 'leer' is 'n onlosmaaklike en lewenslange deel van ons daaglikse bestaan (Lovell 1980:18-19). In wese behels dit 'n voortgesette verandering, op 'n redelike permanente basis, in ons potensiaal tot prestasie en bedrewenheid as gevolg van interaksie met ons wêreld in die verlede (Lovell 1980:30; Dingemans 1986:8687; Lefrancois 1982:4).

Hoe en hoekom hierdie 'leer' by mense plaasvind word by wyse van leerteorieë geformuleer (Hill 1983:17; Swenson 1980:3-7). Binne die kerk is ons goed bekend met die fenomeen 'leer'. Die kerk se prediking, opsighandelinge (Kerkwet 1986:6772), kategetiese (Beukes 1983:8-15; Dingemans 1986:131) sowel as postkategetiese

\footnotetext{
* Voorgelê en aanvaar as deel van die vereistes vir die MDiv-graad, Fakulteit Teologie (Afd A), Universiteit van Pretoria, onder leiding van prof dr T F J Dreyer.
} 
(Nel 1987:45; Richards 1988:40-47, 276-283) geleenthede is immers op die aanleer van verantwoordelike lidmaatskap afgestem. Hierdie artikel fokus spesifiek op die fenomeen 'leer' soos dit betrekking het op die prediking.

Die prediking van die kerk verdiskonteer altyd 'n faset van lering, onderrig en toerusting (Richards 1988:317; Pieterse 1988:32-34; 1986:165-168). Prediking as pneumatologiese woordgebeure wil immers die lidmaat begelei tot 'n ontmoeting met die lewende God asook 'n lewe van eer voor daardie God (Dreyer 1989:365; Pieterse 1986:17). Dit beteken dat die prediking die lidmaat wil 'leer' om verantwoordelike mens voor God te wees - in die woorde van Matteus 28:19 - om God se 'dissipels' of 'leerlinge' te wees (Dingemans 1986:138; Nel 1987:38-42). Pieterse (1989:34) benadruk juis prediking as leergebeure wanneer hy die didache, dit wil sê die oordrag van geloofsinhoude, as integrale deel van die prediking verreken (vgl De Klerk 1977:74-75).

In hierdie artikel word die hipotese voorgehou dat daar 'n bepaalde verband tussen leerteorieë en prediking as leergebeure bestaan. Hoedanig hierdie hipotese aan die orde gestel sal word is afhanklik van die metodologie wat in hierdie artikel gevolg sal word.

\subsection{Metodologie}

Die huidige reeds bekende wetenskapsmodel van metateorieë, basisteorieë en praktykteorieë dien hier as vertrekpunt (kyk Dreyer 1991:1-4). Hierdie teorieë kan metodologies volgens die Zerfassmodel, soos aangepas deur Dreyer (1911:11) ingespan word. Volgens hierdie model kan die teorie en praxis van 'n betrokke wetenskap onbevange in wisse!werking met mekaar geplaas word.

Hierdie artikel verstaan en volstaan onder 'teorie' met die bestaande basisteorieë ten opsigte van teologie (Dreyer 1991:6; Pieterse 1986:2), praktiese teologie (Dreyer 1991:9; Dingemans 1986:16,17) en prediking (Dreyer 1989:365; Pieterse $1986: 5,6,17)$. Aldus hierdie basisteorieë word prediking as 'n kommunikatiewe geloofshandeling beskou wat onder andere op die handelingsveld van die erediens voltrek word (Heyns \& Pieterse 1990:13-15).

Interessant genoeg word vanuit die erediens onder andere ook die geloofshandeling van lering voltrek (Nel 1987:42-45; Richards 1988:193-195). Om die metateoretiese raakvlakke tussen leerteorieë en prediking derhalwe te identifiseer sou beteken dat die geloofshandeling van lering op alle handelingsvelde naas, rondom en bydraend tot die prediking ook verdiskonteer behoort te word. Hierdie metateoretiese werkswyse word ondervang met die 'praxis'-pool van bovermelde Zerfassmodel, naamlik 'n verkenning van bestaande leerteorieë vanuit die wetenskapsvelde van die psigologie, pedagogiek en andragogie. Dit beteken dat die prediking en 
leerteorieë, soos deur ander wetenskappe verwoord, dan om een tafel kan gaan sit. Die gesprek sou dan sentreer om die vrae na watter leerproses(se) in, deur, tydens en rondom die preekgebeure voltrek word asook hoedanig sodanige proses(se) geoptimaliseer kan word. Daar word dus deduktief ondersoek ingestel na die identifisering en kategorisering van leerteorieë wat betrekking kan hê op die prediking.

\subsection{Indeling van artikel}

'n Oorsig van bestaande leerteorieë by wyse van identifisering en kategorisering word allereers aan die orde gestel. Daarnaas word gepoog om die veelvoud van leerteorieë te integreer tot 'n werkbare leermodel om sodoende tot 'n verstaan van die leerproses te kom. Oplaas word daar vanuit 'n eie voorgestelde en geïntegreerde leermodel bepaalde gevolgtrekkings gemaak. Sodanige gevolgtrekkings het, gesien in die lig van die hipotese van hierdie artikel, bepaalde homiletiese implikasies wat in 'n volgende artikel ondersoek sou kon word.

\section{OORSIG VAN BESTAANDE LEERTEORIEe-}

Wie net vlugtig van bestaande leerteorieë wil kennis neem beland bitter vinnig in 'n moeras van verwarring. Drie sake is hiervoor verantwoordelik:

- Daar bestaan steeds gèèn samehangende en algemeen aanvaarde teorie oor hoe 'n mens leer nie (Lefrancois 1982:11).

'n Oorsig van bestaande literatuur in hierdie verband vertoon 'n beduidende eenstemmigheid om leerteorieë in twee hoofstrominge te verdeel (Lieberman 1990:33-35; Hulse 1980:2-7). Enersyds vind mens die assosiatiewe, ook genoem behavioristiese of ' $S$-R'-teorie ë: leer is gelyk aan 'n mens se respons (R) op buite stimuli (S) (Lieberman 1990:318-324). Hierdie S-R verbande lei tot die assosiasie van idees en die vaslegging van 'n gewoonte; leer wil dus tot gedragsverandering lei (Swenson 1980:3-4; Ellis 1979:3-4). Dit val dadelik op dat hierdie benadering meganiese en deterministiese tendense vertoon (Lieberman 1990:143, 339-343).

Assosiatiewe leerteorieë het tot die einde van die 19de eeu nog die septer geswaai (Marx 1987:403). Toonaangewende verteenwoordigers van hierdie benadering wat bespreek sal word is Watson, Guthrie, Thorndike, Miller, Hull en Skinner. Die ander hoofstroom in leerteorieë is die kognitiewe groep (Bolles 1978:192-194; Swenson 1980:101-103). Hiervolgens word gedrag deur breinaktiwiteit bepaal. Leer behels dus veel meer as blote gedragsverandering (Lieberman 1990:161, 324-328) - leer is die verkryging van insig en begrip. Die mens moet eerder holisties benader word veral ten opsigte van sy prosesse van probleemoplossing, persepsie, uitoefening van keuses, prosessering van inlig- 
ting, formulering van konsepte en geheue (Bourne 1986:11-18; Bolles 1978:8589). Kognitiewe teorieë wat alhier aandag sal geniet is Hebb, Bruner, die Gestaltists, Piaget, Tolman, Mowrer en Bandura.

Dit dien reeds hier vermeld te word dat bestaande teorieë selde op rigiede wyse as slegs behavioristies of kognitief afgemaak kan word (Marx 1987:65-67, 420-421; Hill 1985:211-215).

Die verskil tussen die twee kategorieë leerteorieë soos bo vermeld kan met 'n voorbeeld uit die gemeentelewe geillustreer word: waar begin jy om lidmate te leer om mekaar se laste te dra? Indien leer die leer van gedrag is (dws assosiatief), moet jy dan op die grondvlak begin deur lidmate in diensgroepwerk (bv siekebesoek) te organiseer sodat hulle deur ervaring leer om ander se laste te dra. Iemand wat leer as kognitief beskou sal by die prediking begin om sodoende die persepsie van 'laste dra' by lidmate kerugmaties-lerend tuis te bring.

- Daar bestaan redelike duidelikheid en eenstemmigheid oor die prosedures wat leer veroorsaak (Ellis 1979:2-4).

Mààr die eindelike, eintlike en fundamentele leerproses as sodanig bly steeds 'n hoogs debateerbare aangeleentheid (Bolles 1978:137). Geen én leerteorie bied 'n universele beeld van die leer-'proses' nie. Elke teorie sal hoogstens 'n vorm van leer aanwys met bydraende of afbrekende faktore wat die verloop daarvan beïnvloed. Met versigtigheid kan dit gestel word dat die leerproses as sodanig na alle waarskynlikheid rekening moet hou met verskillende leervorme (of te wel tipes van leer) soos deur die verskillende leerteorieë voorgestel. Die leerproses deurloop dus verskeie vlakke van leer waarop genoemde faktore positief (leermotivering) en/of negatief (leerweerstand) inwerk. Leer moet dus as omvattende begrip vir die doeleindes van hierdie artikel geneem word. Leer sou dan assosiatief en kognitief wees! Dit sou in lyn wees met Gagne (kyk Lefrancois 1982:317) se poging om 'leer' eerder as 'n geïntegreerde model, wat prosedure en proses insluit, te beskou.

In analogie met rekenaarterminologie leer die mens assosiatief deur sy 'sagteware', dit wil sê sy ervaring. Sy 'hardeware' is dan hoe hy kognitief leer, naamlik deur middel van sy fisiese, persepsuele en motiveringsvermoëns. Om te leer is dus 'n proses van programskrywing: '...a person is like a computer with a open-ended program that in effect keeps rewriting itself on the basis of its experience' (Hill 1985:216). 
- Daar bestaan verskeie faktore, reeds hierbo vermeld, wat op een of ander wyse die leerproses beinvloed (Lefrancois 1982:309-310).

Hierdie faktore word nie noodwendig in die betrokke teorieë geïnkorporeer nie. Dit raak sake soos beloning op of straf vir tipes gedrag, die geheue naamlik, hoe word nuwe inligting geassimileer en wat is die retensie sowel as herwinningsvermoë van inligting? - elke mens se begripsvermoë en die rol van aandag in die leerproses (Hill 1985:218). Daarby is reeds vermeld dat hierdie faktore as leermotivering of leerweerstand kan fungeer. Hierdie faktore sal beslis verreken moet word in die voorgestelde sintese hierbo genoem. Binne 'n geïntegreerde leermodel sal daar aan hierdie leermotivering/leerweerstande 'n plek toegeken moet word.

\subsection{Assosiatiewe leerteorieē}

Die assosiatiewe leerteorieë word gewoonlik in twee groepe onderverdeel, naamlik kontinue of versterkend. Die onderskeiding geskied op grond van die noodsaaklikheid aldan nie van versterkende faktore in die aanleer van gedrag. Kontinue dui op die afwesigheid daarvan en word derhalwe eerste behandel.

\subsubsection{Assosiatief-kontinue}

Leer is die noodwendige openbaring van 'n respons op stimulus sonder enige versterkende faktore. Die vernaamste verteenwoordigers hiervan is:

\subsubsection{J B Watson (1878-1958): 'leer deur herhaling'}

As basis tot leer vertoon Watson slaafse navolging van Pavlov se klassieke kondisionering (Hill 1985:23): naas 'n nie-geleerde genetiesbepaalde respons op 'n spesifieke stimulus kan kondisionering van dieselfde respons op ander stimuli plaasvind.

Op een lyn hiermee beweer Watson dan dat die mens ingebore gedragsmoontlikhede van slegs 'n paar reflekse het (Bolles 1978:46; Bourne 1986:23-24). By wyse van herhaalde response op sekere stimuli van buite, leer die mens dan aan om op ander stimuli te respondeer (die sg 'law of frequency'). Sodoende sorg omgewingstimuli vir die vorming van die mens se persoonlikheid, intelligensie en die aanleer van emosies. Watson as voorloper van die behaviorisme sal dan ook onthou word vir die uitspraak dat hy met twaalf gesonde babas enigiets kan bereik, dokter of dief, solank hy vrye teuels in hulle opvoeding gegun word (Hill 1985:29). Ons is dus wat ons geleer het! 


\subsubsection{E R Guthrie (1886-1959): 'Teer deur doen'}

Guthrie gaan verder as Watson deur ' $n$ S-R verband as oombliklik te beskou, dit wil se 'n gegewe respons op 'n gegewe stimulus word met die eerste keer wat dit plaasvind vasgelè (Swenson 1980:4). Die respons hoef nie herhaaldelik geoefen te word om die S-R verband te verstewig nie. Leer vind dus oombliklik en derhalwe aanhoudend plaas aangesien elke respons tegelyk 'n kondisionering aan bestaande stimuli is en 'n dekondisionering van die vorige respons. Doen jy iets in 'n spesifieke situasie sal jy volgende keer in 'n soortgelyke situasie geneig wees om weer daardie selfde iets te doen. Gewoonlik sal dit die laaste iets van die eerste situasie wees wat nou mee begin sal word in die tweede situasie. Die rede hiervoor is dat die aanvanklike $S-R$ verbande so stewig in die geheue vasgele is dat dit nooit vergeet kan word nie (Marx 1987:348). Hiermee wou Guthrie poog om die komplekse en onvoorspelbaarheid van gedrag tuis te bring in sy leerteorie. Guthrie bly getrou aan die behavioristiese benadering deur die gevolge van gedrag nie in te reken as versterkend tot die leerproses nie (Bolles 1978:59). Daarmee word bedoel dat straf en beloning asook motivering blote stimuli is wat verhoed dat respons afgeleer word. Ons leer dus, nie deur sukses of versterking nie, slegs deur doen. Die verskil tussen Watson en Guthrie lê juis hier: Watson huldig 'n aanhoudende doen (bv hoe meer 'n kind rook hoe minder gaan jy hom leer om op te hou) terwyl Guthrie dit wat laaste gedoen word as aangeleer beskou (bv om genoemde kind se slegte rookgewoonte af te leer laat hy aanhou rook tot hy moeg is daarvoor).

\subsubsection{Assosiatief-versterkend}

Die tweede onderafdeling in die assosiatiewe groep van leerteorieë is die van versterking. Hierdie teorieë wil leer nie uitsluitlik as 'n stimulus-respons verband beskou nie; beloning word as essensieël gereken om die toepaslike respons aan te leer (Swenson 1980:50; Lefrancois 1982:35-36). Vooraanstaande teoretici van hierdie benadering is:

\subsubsection{E L Thorndike (1874-1949): 'leer deur versterking'}

Thorndike vertoon 'n beduidende breuk met die voorafgaande teorieë (Swenson 1980:52). Teenoor Watson sien hy leer as die vorming van nuwe S-R verbande. Hierdie 'law of effect' beteken dan dat die respons wat lei tot 'n positiewe gedrag van sake meer geneig sal wees om herhaal te word. Waar 'n stimulus gevolg word deur 'n respons en 'n 'satisfier' word die S-R verband versterk; waar 'n 'annoyer' volg vind S-R verswakking plaas (Hill 1985:45). 
Thorndike wil leer dus as afhanklik van versterkingsfaktore beskou, dit wil sê deur jou respons wil jy iets laat gebeur. Voortvloeiend daaruit praat Thorndike dan ook van die 'law of exercise' (Bolles 1978:15). Daarmee neem hy teenoor Guthrie stelling in deur voor te stel dat $S-R$ verbande ingeoefen moet word om vasgelè te word. Hieruit is dit dus duidelik dat die leerproses essensieël 'n 'stamping-in' proses behels. Tog geskied hierdie proses nie heeltemal outomaties nie. Thorndike se 'law of readiness' (Swenson 1980:53-54) bepaal dat jy gemotiveer moet wees om op te tree.

\subsubsection{N Miller (1909-): 'leer deur beloning en nabootsing'}

Vele het op die toonaangewende benadering van Thorndike verbeter en uitgebrei; Miller tel onder die eerstes daarvan (Marx 1987:66). Teenoor Thorndike se 'trial and error' leerbasis beskou hy dryfveer as basis tot leer (Hill 1985:47). Hierdie dryfveer by 'n organisme kan enige innerlike (bv dors) of uiterlike (bv pyn) stimulus wees wat sterk genoeg is om optrede te motiveer.

Daardie respons wat die dryfveer bevredig, word dan aangeleer. In samewerking met J Dollard (1900-1980) het Miller sy teorie toegepas op die nabootsingsgedrag by mense (Swenson 1980:162). Ander se optrede dien dan as stimuli vir my eie respons en so leer ek om te doen wat ek sien ander doen. Miller en Dollard se eksperimente het dan ook aangetoon dat daar onderskei kan word tussen wie ek wil naboots al dan nie (Hill 1985:49).

\subsubsection{C L Hull (1884-1952): 'leer deur gewoonte'}

Hull as mees invloedryke leerteoretikus van sy tyd kritiseer Thorndike daarin dat sy leerteorie die rol van motivering onderskat. Vir Hull is gedrag altyd doelgerig. Die rasionaal agter $\mathrm{S}-\mathrm{R}$ verbindings is dus volgens hom, soos by Miller, die dryfveer aanwesig by die organisme. Met verwysing na Miller noem Hull dan die verbinding tussen stimulus en beloonde respons wat herhaal sal word'n gewoonte (Lefrancois 1982:77). ' $n$ Gewoonte dui dan op die intensiteit van die $S-R$ verbinding en word deur Hull aangedui as SHR (waar ' $H$ ' vir 'habit'/gewoonte staan). Leer behels dan die vorming en versterking van gewoontes. Gewoontes word versterk deur die persoon se respons soos by Miller, te beloon (Bolles 1978:92-97). Aldus Hill (1985:58) kan Miller se 'dryfveer' as 'wanting the thing that is to be gained' beskryf word, terwyl Hull se 'gewoonte' beteken 'knowing what is to be gained by doing it'. 


\subsubsection{B F Skinner (1904): 'leer deur gevolge'}

Skinner is sekerlik die bekendste leertoeretikus van die 1980's (Modgil 1987:1). Hy verteenwoordig 'n posisie ten opsigte van leerteorieë wat die reeds behandelde kategorieë van assosiatief-kontinue en assosiatief-versterkend probeer integreer (Hill 1985:63). Klassieke kondisionering verteenwoordig vir Skinner een vorm van leer, naamlik responsgedrag: 'n respons word gewek en beheer deur 'n spesifieke stimulus. Daarteenoor staan 'n tweede en prominente leervorm, naamlik 'operante' gedrag: 'n respons word toegeskryf aan die gevolge wat sodanige respons teweeg sal bring (Hill 1985:64-65). Gedrag word derhalwe gewissel sodat die organisme leer om in sy milieu te opereer, dit te modifiëer en eindelik te beheer.

\subsubsection{Kritiek}

Die assosiatiewe leerteorieë bevat die volgende tekortkominge:

* Meganisering en gevolglik ontmensliking van die mens (Goldstein 1981:35-41; Lefrancois 1982:34-35; Knowles 1978:15-17).

Dit spreek duidelik uit die feit dat eksperimente op diere uitgevoer is en dan in algemene sin op menslike gedrag van toepassing gemaak is. Imelman (in Dingemans 1986:86) beskou, inteendeel, 'leer' as 'n definitiewe menslike moontlikheid. Van Parreren (in Dingemans 1986:87) opper ook sy beswaar teen ' $n$ gelykstelling van mens en dier wanneer dit by leer kom. Hy beskou die assosiatiewe leerteorieë as unitaristies, naamlik, alle leer moet gereduseer word tot die gemeenskaplike noemer van reaksie op stimuli. 'n Meer pluralistiese benadering hou daarmee rekening dat leer ook die prosesse van inoefening, nabootsing en inligtingsverwerking deurloop.

Dat die behavioriste minstens na objektiwiteit streef moet hul toegereken word (Lieberman 1990:338-342). In hierdie opsig is hul minder spekulatief as die kognitiewe leerteoretici.

- Kondisionering is 'n oorvereenvoudiging en onrealistiese beskrywing van leer (Lefrancois 1982:102-103).

Die mens se interaksie met sy omgewing is tog meer as blote response op stimuli. Richards (1988:72-73) sluit hierby aan deur die behavioriste se teorieë een- of twee-faktor teorieë te noem. In die eerste geval word mens en omgewing wesenlik gelykgestel en in die tweede geval staan die mens minstens apartonderhandelend tot sy omgewing. Sy onderhandelende interaksie met sy omgewing beteken dat hy aktief alle stimuli probeer integreer. 


\subsection{Kognitiewe leerteorieë}

Teenoor die assosiatiewe leerteorieë staan die kognitiewe leerteorieë. Hiervolgens word die leerproses eerder as kreatiewe denkproses beskou (Bourne 1986:11-18; Bolles 1978:85-89). Die oorgangstydperk van leer as blote S-R verbande tot sodanige benadering word derhalwe eerstens behandel. Daarna kan kognitiewe leerteorieë in twee onderafdelings ingedeel word, naamlik navorsing ten opsigte van leer as denkproses op Europese bodem en dan leerteoretici wat via 'n behavioristiese benadering na 'n kognitiewe siening beweeg het (Hill 1985:88, 112, 132, 141, 151).

\subsubsection{Oorgangstydperk}

In 'n mens se nadenke oor die assosiatiewe leerteorieë stuit 'n mens telkens op een vraag: wat presies gebeur tussen die stimulus en die respons dat daar enigsins 'n verband vasgelê word? Thorndike, Miller, Hull en Skinner beantwoord die vraag in terme van motiveringsfaktore. Hieruit spreek dit vanself dat daar in die S-R verband tog iets kognitiefs opgesluit lè. Hebb en Bruner poog dan juis om 'n leerteorie rondom hierdie 'iets kognitiefs' op te stel (Lefrancois 1982:106-107, 160162).

\subsubsection{D O Hebb (1904): 'leer deur breinaktiwiteit'}

Hebb lokaliseer die basis vir gedrag in hoër denkprosesse van die mens (Lefrancois 1982:105-106). Leer is dan gesetel in die neuronaktiwiteit van die brein. Hebb kom tot hierdie slotsom na aanleiding van die vraag wat in die tydsverloop tussen ' $n$ stimulus en 'n respons gebeur: vir hom lê dit in die 'ocurrence of processes which, themselves independent of immediate sensory input, collaborate with that input to determine which of the various possible responses will be made' (Lefrancois 1982:107). Hebb poog nie om 'n teorie daar te stel nie; eerder die daarstelling van neurologiese en fisiologiese hipoteses.

Resente breinnavorsing beklemtoon in toenemende mate Hebb se aanvoelings. Insiggewend is dan die gedagte dat 'n mens se twee hemisfere van die brein van mekaar verskil ten opsigte van leervermoë en die kreatiewe strategieë om ervaring aan te wend ten opsigte van denke en gedrag (Trevarthen 1986:180).

\subsubsection{J S Bruner: 'leer deur kategorisering'}

Bruner bou voort op Hebb se neurologiese-fisiologiese basis vir gedrag. Allereers deur ons voorstelling van ons omgewing drieërlei te verduidelik (Lefrancois 1982:161-162). Ons sien ons wêreld in terme van objekte, beelde (die kognitiewe ekwivalent van fisiese objek) en simbole. Daarnaas sien Bruner die vorming en 
benutting van hierdie drieledige voorstellings as 'n kategoriseringsproses (Lefrancois 1982:162). Leer behels dan die vermoë en strategie om stimulusgebeure in terme van hulle attribute te klassifiseer. Op hierdie wyse kom die mens tot insig en die formulering van konsepte. Die hele bedoeling met leer is om juis tot meer as net die insameling van gegewe inligting te kom. Bruner beskryf kategorisering as volg: '...to render discriminably different things equivalent to group the objects and people around us into classes, and to respond to them in terms of their class membership rather than in terms of their uniqueness' (Lefrancois 1982:163). Die leerder prosesseer dus inligting by wyse van keuse-uitoefening tot 'n sisteem van verbandhoudende kategorieë wat hom 'n algemene herwinningsveld bied. Algemene kategorieë word voor spesifieke kategorieë aangeleer (Lefrancois 1982:166-167). Ons interaksie met die wêreld om ons is dus hoofsaaklik in terme van ooreenkomste en verskille tussen objekte en gebeure wat ons waarneem.

\subsubsection{Die Europese tradisie}

Ontwikkeling in Europa rondom leerteorieë kan hoofsaaklik aan die Duitsers (hiernaas as die Gestaltists bespreek) en die Fransman Piaget toegeskryf word (Hill 1985:88-89, 103-104; Bourne 1986:24-27).

\subsubsection{Die Gestaltists: 'leer deur situasie-insig'}

Hierdie begrip wil die 20ste eeuse rigting in die psigologie ten opsigte van sintesis aandui: die geheel van denkpatrone (Duitse gestalt beteken 'vorm') is meer as die somtotaal van die verskillende dele (Hill 1985:89-91). Iets daarvan kom reeds by Watson voor in sy molêre in plaas van molekulêre benadering in wetenskap (Bolles 1978:45). Daarmee word bedoel dat leer as geheelproses in plaas van losstaande fasette bestudeer moet word. Wat Watson vir Amerikaanse psigologie gedoen het, het M Wertheimer (1980-1943), as voorloper van die Gestaltists, vir Duitse psigologie gedoen (Marx 1987:195-198). Wertheimer sien ons denke as 'n geheelbeeld van betekenisvolle persepsies, eerder as geassosieerde versamelings van beelde (Swenson 1980:116, 149). Hiermee vestig Wertheimer die kenmerkende van die Gestaltists se leerteorieë, naamlik 'n verwerping van die 'trial-and-error' verduideliking van menstike leer soos by die assosiatiewe leerteorieê: leer geskied eerder deur insig. Wertheimer inisieër dus 'n dinamiese benadering ten opsigte van leer naamlik, die menslike bewussyn leer om die verskillende verbandhoudende fasette van 'n situasie so te begryp dat hy dit integreer tot bestaande denkpatrone. Deur middel van insig leer ek dus om die situasie op 'n nuwe manier te bekyk. W Kohler (1887-1967) en K Koffka (1886-1941) het Wertheimer se insigte so effe verfyn (Lefrancois 1982:141-144). Hulle formuleer 'leer deur insig' aan die hand van 
die wette van nabyheid en geslotenheid. Die wet van nabyheid beteken byvoorbeeld dat onlangse gebeure onthou word omdat jy dit nader aan die teenswoordige tyd geleer het. Geslotenheid dui op die individu se worsteling met 'n probleem totdat hy die antwoord gekry het; jy vorm dus 'n geslote sisteem in jou denke met die oog op doelbereiking (die assosiatiewe leerteorieë sou hier van beloning of versterking praat; Lefrancois 1982:144-145).

K Lewin (1890-1947), as 'n verdere verteenwoordiger van die Gestaltists, word vermeld aangesien hy bietjie ander klem gelê het (Hill 1985:97): waar die Gestaltists vra na hoe doelwitte bereik word deur kognitiewe herstrukturering, wil Lewin meer konsentreer op dit wat agter die doelwitte self sit. In die verband praat hy van 'n persoon se lewensruimte as synde daardie persoon se omgewing soos hy dit sien, begryp en dit op hom inwerk (Hill 1985:98-100; Goldstein 1981:99, 147-152). Binne hierdie lewensruimte het die persoon bepaalde doelwitte wat hy wil bereik maar hy het ook met struikelblokke te kampe in die bereiking daarvan. Ek moet dus bepaal watter pad ek in hierdie lewensruimte van my moet loop. Hiermee bied Lewin meer 'n sisteem van hoekom tree iemand nou so op en so sou hy sekerlik in die toekoms optree. 'n Leerteorie het hy eintlik nie, behalwe om te sê dat leer die lewensruimte aanpas.

\subsubsection{J Piaget (1896-1980): 'leer deur akkomodasie en assimilasie'}

Piaget is eintlik 'n ontwikkelingspsigoloog (kyk Louw 1983:195-196). Leer en ontwikkeling loop vir hom tog hand aan hand. Dis juis die ander kognitiewe teorieë se tekortkoming: hoe verander begrip, motivering en probleemoplossing van die kind na volwassene? Ontwikkeling van die mens is immers sy toenemende vermoë om op 'n toepaslike, realistiese en logiese wyse met sy wêreld in interaksie te tree (Hill 1985:104). Piaget noem dit ons schemata; die vorming en verandering hiervan is die basis tot kognitiewe ontwikkeling (Louw 1983:196-198). Hierdie kognitiewe ontwikkelingstadia verloop hiërargies-integrerend tot mekaar:

- sensories-motories (0-2jr): hier ontwikkel die 'schemata' van basiese persepsies van die fisiese omgewing asook koordinasievermoë om die omgewing te bemeester.

* pre-operasioneel, dit wil sê prekonseptuele en intuitiewe denke (2-7jr): objekte en gebeure kan simbolies bedink en geverbaliseer word.

* konkreet-operasioneel (7-11jr): die omgewing word volgens konsepte geklassifiseer, gekombineer en vergelyk en omgekeerde denke vind ook plaas, byvoorbeeld in die vorige fase sal die kind nog sê, 'Ek het 'n boetie, maar hy't geen boetie nie'.

* Formeel-operasioneel (11-16jr): die hoogtepunt van abstrakte denke. 
In die mens se interaksie met sy omgewing, dit wil sê sy schemata, word die prosesse van assimilasie - die vermoë om reeds aangeleerde gedrag weer te gebruik, dit wil sê, dit wat ons ervaar, word in die lig van die bestaande schemata van wat ons reeds weet en glo geïnterpreteer - en akkomodasie (die vermoë om gedrag te verander, dws bestaande schemata pas aan by nuwe ervarings) tot 'n optimale ekwilibrium voltrek: dit noem Piaget die mens se intelligensie (Dingemans 1986:102). Met verwysing na die behavioriste beteken dit dat 'n stimulus tot bestaande schemata geassimileer word. Piaget verskil juis van Lewin daarin dat hy rekening hou met 'n mens se lewensruimte en sy eksterne omgewing. Assimilasie benadruk dat ons gedrag beinvloed word deur ons geïnterpreteerde omgewing. Akkommodasie aan die ander kant gee toe dat ons eksterne omgewing ons voortdurend uitdaag om anders na dit te kyk. 'Indeed, no behavior, even if it is new to the individual, constitutes an absolute beginning. It is always grafted onto previous schemes and therefore amounts to assimilating new elements to already constructed structures' (Foster 1985:98). Daar is by die leerder altyd 'n mate van begrip reeds aanwesig en daarom word nuwe inligting deur middel van assimilasie aangepas om by die hoorder se bestaande skemas in te pas. Deur die leerder tot disekwilibrium te bring (dws sy bestaande skemas as verkeerd of ontoereikend uit te wys) veroorsaak jy akkommodasie, dit wil sê nuwe skemas word gevorm.

Forster (1985:99-101) het 'n geweldige stimulerende vergelyking getref tussen hierdie leervorm en Christus se lering: Sy prediking was die 'goeie nuus' aan mense met bestaande Judaïstiese godsdiensskemas sowel as die heidene. Hy begin dan deur gelykenisse te vertel waarmee $\mathrm{Hy}$ hulle bestaande skemas van alledaagse ervaringe aktiveer. Tog bou hy 'eienaardighede' in die gelykenisse in om sy hoorders tot disekwilibrium te bring (bv die verlore seun word vergewe, mense verwerp die troue uitnodiging, 'n werknemer betaal dieselfde vir een of twaalf ure se werk). Vandaar begelei Hy dan 'n wettisisme tot 'n lewenswyse van liefde (bv die bergpredikasie).

\subsubsection{Behavioristiese tradisie}

Die Amerikaanse psigologie kon nooit werklik loskom van Thorndike se trial and error' behaviorisme van leer nie (Lefrancois 1982:139-141). Die volgende leerteoretici het almeer hul misnoeë uitgespreek ten opsigte van die behavioriste se onvermoë om die mens se denkprosesse te verklaar: 


\subsubsection{E C Tolman (1886-1959): 'leer deur doelgerigtheid'}

Tolman verruil sy aanvanklike behavioristiese ingesteldheid vir 'n meer kognitiewe benadering (Lieberman 1990:335). Gedrag is nie soseer refleksief in terme van eenvoudige en eenlynige S-R verbindings as wat ons dink nie. Gedrag is altyd gerig op doelbereiking. Om verwarring met Hull te voorkom moet dit duidelik gestel word dat Hull met dryfveer 'n stimulus bedoel. Tolman sien dryfveer eerder as 'n kognitiewe verwagting by die organisme dat hierdie respons hierdie belonende gevolg sal hê. Hy beskryf sy teorie gevolglik as die van doelgerigte behaviorisme (Swenson 1980:104). Tolman sluit dus aan by Lewin se gedagte van die lewensruimte maar beklemtoon meer die eksterne stimuli vanuit daardie lewensruimte. Behoeftes vanuit daardie lewensruimte veroorsaak dryfkragte met die oog op doelwitte. Hierdie dryfkragte vertoon 'n kognitiewe strukturering, wat Tolman 'cognitive maps' noem, waarvolgens response dan gewek word (Hill 1985:114-117). Ruimte word dus gelaat vir 'n meer buigsame leervorm, byvoorbeeld 'instinktief' sal 'n voël ' $n$ nes bou maar sy middele daartoe is nie so deterministiesbepaald as wat behavioriste te kenne wil gee nie. Die voël benut sy 'cognitive maps' van vorige ervarings met betrekking tot nesbou waar dit nou weer ' $n$ nuwe nes moet bou. Leer is dus nie atomisties in terme van $S-R$ verbindings te beskryf nie maar eerder holisties in terme van die organisme se aanpasbare, kreatiewe en intellektuele fasette. Essensieël tot ' $n$ verstaan van Tolman is dat leer latent bly indien die doel, motivering of verwagting ontbreek (Lefrancois 1982:138-139).

\subsubsection{O H Mowrer (1907-1982): 'leer deur aanmoediging'}

Mowrer se besondere bydrae lê by die aanleer van emosionele response (Swenson 1980:166-171; Marx 1987:372). Ter illustrasie - wat versterk 'n kind, wat brandwonde opgedoen het, se optrede om byvoorbeeld vuur te vermy? In lyn met 'n behavioristiese verklaring sou Miller en Hull sê die vermindering van pyn. Mowrer sien die vuur byvoorbeeld as direkte versterker. Hiermee val Mowrer terug op Skinner se twee leervorme van response en 'operante' gedrag. Hy gebruik net ander begrippe, naamlik tekenleer (bv die stoof as gekondisioneerde stimulus vir die ongekondisioneerde stimulus van pyn dien as teken van gevaar en wek dan 'n emosionele en onwillekeurige respons van vrees) en oplossingsleer (willekeurige response kom voor om die dryfveer te bevredig; Hill 1985:142-143). Mowrer sien hierdie twee leervorme eerder as twee fases van leer. Hy het self sy teorie later aangepas deur tekenleer voorop te stel deur te sê dat stimuli nie soseer response wek as dat hulle sekere betekenisse aanneem. 


\subsubsection{A Bandura (1925-): 'leer deur modellering'}

Bandura het gesorg dat Miller en Dollard se inisiatiewe rondom leer deur middel van nabootsing tot sy volle reg in 'n leerteorie kom (Lefrancois 1982:285). Miller en Dollard se teorie was 'n simplistiese 'follow the leader'. Bandura verbreed die begrip nabootsing tot modellering wat dan die proses van identifisering insluit, dit wil sễ poog om soos iemand anders te wees (Lefrancois 1982:289-294; Hill 1985:151155). In modellering vervaag die skerp onderskeid tussen leer deur waarneming en leer deur luister. Ek leer nie response aan nie maar kennis oor response en hulle gevolge. Deur middel van modellering leer ek dan ook om reeds aangeleerde response te inhibeer.

\subsubsection{Kritiek}

Kognitiewe teorieë se spekulasie oor die neurologiese en fisiologiese basisse tot gedrag het dikwels die kritiek ontlok dat sodanige teorieê nie veel help ten opsigte van die praktiese bruikbaarheid daarvan nie (Bourne 1986:2, 23; Hill 1985:213; Knowles 1978:23-26).

Tog word temas aangesny wat meer relevansie tot gedrag openbaar as die behavioriste se vrae rondom S-R verbindings. Tolman, Mowrer en Bandura staan eintlik tussen die assosiatief-kontinue teorieë en die ander kognitiewe teorieë deurdat hulle kognitiewe strukture as maklik veranderbaar beskou (meer as bv Piaget). Hulle posisie kan inteendeel geklassifiseer word as die van sosiale leerteorieë (Lefrancois 1982:282). Richards (1988:76) wys daarop dat die kognitiewe leerteorieë heel tereg 'n derde faktor bybring in die mens se interaksie met sy omgewing. In sy interaksie met sy omgewing word alle stimuli nie bloot geïntegreer nie. Sy kognitiewe vermoë bepaal hoe hy omgewingsdata begryp en prosesseer. Dit kan nie nagelaat word dat Richards aan die anderkant die kognitiewe psigoloë kritiseer vir die feit dat ' $n$ verdere vierde faktor by die leerproses by hulle ontbreek. Richards wil 'n openbaringsdimensie, vanuit die Christelike geloof, toevoeg aan die mens/omgewing interaksie. In sy interaksie met die 'natuurlike' omgewing het die mens al by werklikheidskonstrukte uitgekom soos byvoorbeeld dat oorlog bo vrede gewaardeer word. Tog behoort die mens ook in interaksie met die 'bonatuurlike' omgewing te wees om tot morele konstrukte te kom.

\section{POGINGS TOT 'N INTEGRASIE VAN LEERTEORIEē}

Vervolgens word gepoog om bestaande leerteorieë tot 'n singewende en werkbare model te integreer. Die bruikbaarheid van Gagne se geïntegreerde leermodel word allereers voorgehou met verwysing na die bestaande leerteorieë. Aan die hand van 
Maslow word die basiese vraag tot die leerproses - hoekom leer mense, aldan nie (nl leermotivering en leerweerstand) - by Gagne ingewerk. Eindelik word 'n eie leermodel voorgestel deur Gagne en Maslow te integreer.

\subsection{R Gagne (1916-) se integrasiemodel}

Gagne se leermodel onderskei tussen die 'hoe' en die 'wat' van leer (Lefrancois 1982:317-318). Onder die 'hoe' van leer verstaan hy mens se intellektuele vermoëns. Dit gee aanleiding tot agt leervorme. Hierdie leervorme korreleer in 'n groot mate met voorafgenoemde leerteorieë. Elke leervorm bou dan hiërargies op die vorige een voort. Die eerste vier leervorme is nie-kognitief van aard aangesien die aangeleerde response buite die denke om geskied en dan in vaste gedragspatrone stol. Leer is dan blote gedragsverandering. Wat in die mens gebeur bly ' $n$ raaisel. Daarenteen wil die kognitiewe leervorme erkenning verleen aan die menslike denkproses as kreatief. Myns insiens kan Gagne met etlike terminologiese wysigings en byvoegings voorgestel word volgens die piramide wat hiernaas weergegee word en van onderaf boontoe gelees moet word (kyk Lefrancois 1982: 318-319). Die nie-kognitiewe leervorme berus dus op 'n 'trial and error'-basis: al soekende en struikelend leer jy die regte respons op die stimulus aan. Hierdie S-R verband word dan in die geheue vasgelê vir toekomstige herwinning. By die kognitiewe leervorme word benadruk dat die mens aan die stimuli vanuit die werklikheid betekenis toeken deur die stimuli te kategoriseer, daaruit begrippe oor verskillende konkrete verskynsels te vorm en uiteindelik ook interpretasies daaraan toe te ken. Die hoogste en mees kreatiewe wyse van leer is dan die van probleemoplossing. Opvallend genoeg kom nabootsing op hierdie vlak na vore. Die verskil is net dat die nabootsing uitloop op 'n aanpassing van die oorgenome gedrag of waardes. Leer wil dus uiteindelik lei tot gedragsverandering maar dan aan die hand van probleemoplossing. Die mens moet dus leer om tot selfverantwoordelikheid te kom deur die piramide van onder tot bo te deurloop.

Gagne se leervorme soos dit korreleer met bestaande leerteorieë bied 'n duidelike antwoord op hoe mense leer! Hoekom die mens leer, aldan nie, bly steeds onbeantwoord! Daarop word vervolgens ingegaan. 


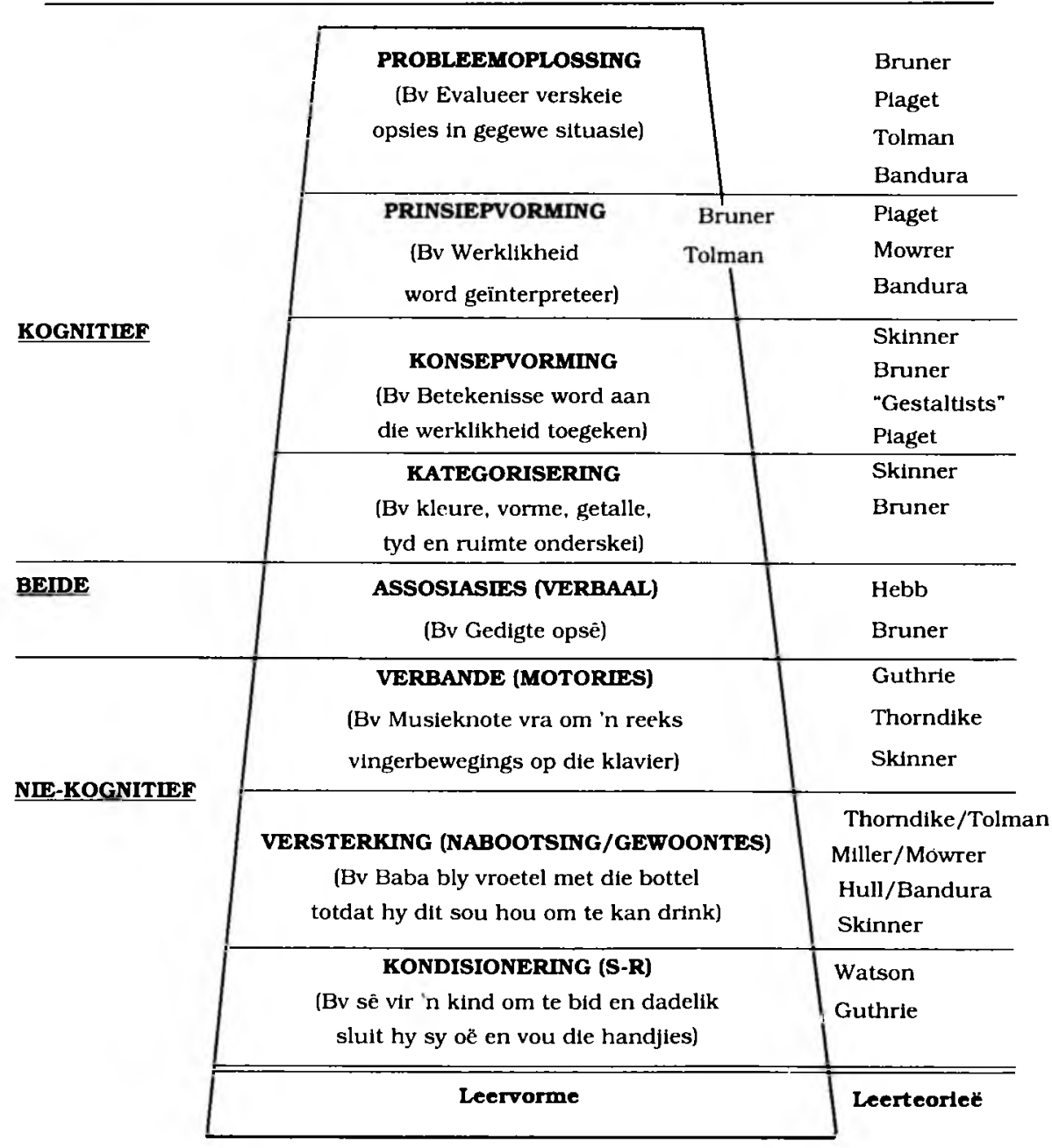

Gagne se leervorme soos dit korreleer met bestaande leerteorieë

\subsection{Leermotivering/leerweerstand as basis vir ' $n$ integrasiemodel}

Gagne se piramide van leervorme bied inderdaad 'n werkbare en sinvolle integrasie van leerteorieë. Tog sou 'n leermodel aan een basiese uitgangspunt moet voldoen: waarom leer of leer mense nie? Leermotivering, as die intrinsieke en eksintrieke dryfkrag agter gedrag, behoort as uitgangspunt te dien vir die daarstelling van 'n 
leermodel van geïntegreerde leerteorieë. Die invloedryke Maslow (Engler 1985: 305; Dingemans 1986:109) bied sodanige motiveringskema in die vorm van 'n behoeftepiramide wat van onder na bo gelees word:

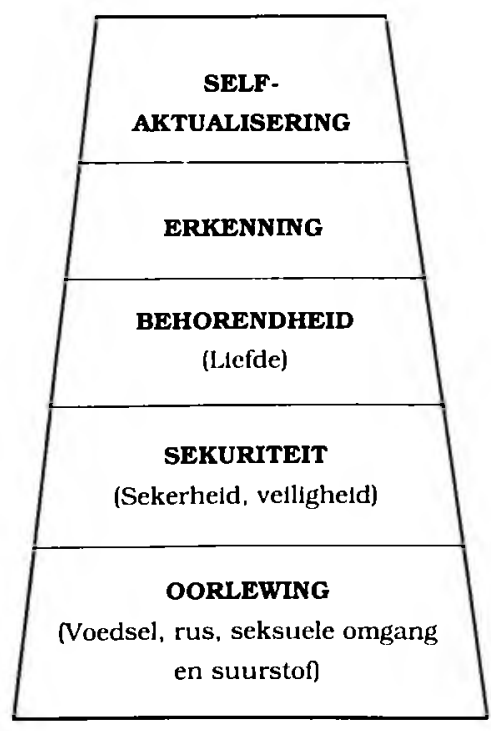

Maslow se behoeftepiramide

Maslow se behoeftepiramide kan kortliks soos volg verduidelik word (Lovell 1980:110-111; Goldstein 1981:417-418; Engler 1985:307-310):

- Oorlewing - Die liggaam se onvermydelike en lewensonderhoudende fisiologiese behoeftes wat grotendeels die mens se bewussyn domineer ten opsigte van die bevrediging daarvan. Sodra die fisiologiese behoefte bevredig is sal die mens sy gedrag herorganiseer met betrekking tot die volgende behoeftevlak in die hiërargie.

* Sekuriteit - Die mens het behoefte daaraan om sy wêreld deur middel van filosofie, godsdiens en wetenskap tot 'n ordelike, beheerbare en bekende gemeenskap te organiseer. Met sodanige sekuriteit is hy oop vir nuwe ervaringe.

* Behorendheid - Die individu se nood aan intieme verhoudings asook sy affiliasie tot allerlei referensiegroepe. Sodoende beleef hy vertroue, begrip en aanvaarding. 
* Erkenning - Elkeen koester 'n selfwaarde. Dit word allereers gevorm deur selfvertroue wat voortspruit uit selfrespek, persoonlike prestasie, vryheid en onafhanklikheid. Daarnaas het elkeen die behoefte aan status, reputasie, respek, en die waardering van andere. Sodoende kweek die individu 'n gevoel van bruikbaarheid en noodsaaklikheid.

* Selfaktualisering - Die behoefte uniek aan elke mens asook verskillend van mens tot mens om sy eie potensiaal te verwesenlik: 'What a man can be, he must be!' (Lovell 1980:111). Op hierdie behoeftevlak behoort die mens raak te sien wat hy kan wees; behoort hy homself te kan losmaak van tradisie en sosiale eise om sodoende hom aan sy eie standaarde te oriënteer. Dis die mens se 'peak experience' (Goldstein 1981:418) van persoonlike kreatiwiteit as uitdrukking van sy outonome self. Selfaktualisering is alleen moontlik wanneer die onderste behoeftes bevredig is.

Dit spreek vanself ciat hierdie behoeftes as leermotivering of leerweerstaande kan dien. Die onderste behoeftes se vervulling, aldan nie, bied die motivering of weerstand om tot selfaktualisering te kom (Dingemans 1986:109). Die onderste behoeftes moet dus vervul word alvorens die boonste behoeftes bevredig kan word.

Ten opsigte van Maslow sou mens wel die stukkie kritiek moet openbaar: innerlike behoeftes kan tog nie die finale woord spreek oor mense se leervermoë aldan nie. Soos geblyk het uit die kritiek op die assosiatiewe leerteorieë is die mens nie 'n dier nie; 'n veelvoud van faktore kan sekerlik toesien dat die mens ook tot selfaktualisering kom sonder die vervulling van onderste behoeftes (Dingemans 1986:109). Verwagtinge buite die mens om dra ook tot sy leerproses by. Maslow verreken juis hierdie aspek deur die behoefte aan kennis en begrip as onderliggend tot sy behoeftepiramide te beskou (Lovell 1980:111-112), byvoorbeeld kennis help om sekuriteit te bewerkstellig en dit kan bydrae tot die bereiking van selfaktualisering. Maslow bied dus 'n oorkoepelende motiveringskema wat eenvoudig en bruikbaar is. Sy behoeftepiramide verskaf ' $n$ handige verwysingsraamwerk vir die intrinsieke dryfkrag agter mense se gedrag. Sodanige verwysingsraamwerk kan dan tegelyk aangewend word om aan te dui welke leervorme mense sal benut om hulle behoeftes te bevredig. Sou die volgende voorbeeld dalk as belaglik afgemaak kon word: die kind 'leer' om kerk toe te gaan deur middel van kondisionering en versterking omdat dit korreleer met sy behoefte aan oorlewing en sekuriteit, dit wil sê, hy wil nie graag 'n pak slae kry nie en nou gaan hy saam met sy ouers kerk toe al wil hy nie.

Hiermee wil ek poog om leervorme en leermotivering/leerweerstand met mekaar te korreleer. Die uitdaging alhier is om te sê waarom (Maslow se behoeftepiramide) mense op 'n bepaalde wyse (Gagne se leervorme) leer. 
3.3 'n Eie leermodel op grond van 'n integrasie van Gagne en Maslow

\begin{tabular}{|c|c|c|c|}
\hline KOGNITIEF/VOLUNTATIEF & & 8. PROBLEEMOPLOSSING & \multirow[t]{2}{*}{ SELFAKTUALISERING } \\
\hline KOGNITIEF/AFFEKTIEF & \multirow{3}{*}{ 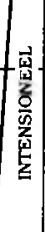 } & 7. PRINSIEPVORMING & \\
\hline KOGNI- & & 6. KONSEPVORMING & \multirow[t]{2}{*}{ ERKENNING } \\
\hline TIEF & & 5. KATEGORISERING & \\
\hline ASSOSIATIEF/KOGNITIEF & 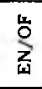 & 4. ASSOSLASIES (VERBAAL) & \multirow[t]{2}{*}{ BEHORENDHEID } \\
\hline ASSOSIATIEF/ & \multirow[b]{2}{*}{$\begin{array}{r}3 \\
5 \\
5 \\
0 \\
\end{array}$} & 3. VERBANDE (MOTORIES) & \\
\hline VERSTERKEND & & 2. VERSTERKING & SEKURITEIT \\
\hline ASSOSIATIEF / KONTINUE & & 1. KONDISIONERING & OORLEWING \\
\hline Leerteorteë & & Leervorme & rmotivering/Leerweerstand \\
\hline
\end{tabular}

Skematiese voorstelling van die verbande tussen bestaande leerteorieë, Gagne se leervorme en Maslow se motiveringskema (word gelees van onder na bo). 
Die leerteorieë en leervorme asook die faktore in leermotivering/leerweerstand waarna bostaande piramide verwys, is reeds voldoende in hierdie artikel uiteengesit. Tog is dit dringend noodsaaklik om op hierdie punt onsself te herinner aan die essensieël dinamiese aard van die leerproses soos aan die begin van hierdie artikel gestel. Soos wat die leerproses dus verskeie leervlakke deurloop, soos blyk uit die piramide hierbo, kan leer spontaan en/of intensioneel geskied (Richards 1988:196199, 206-219; Dingemans 1986:153-154; Lovell 1980:19-21). My intensie as prediker binne die georganiseerde ruimte van die prediking en erediens is om die gemeente oor 'n spesifieke saak te onderrig. Die lidmaat se eie verwysingsraamwerk (Pieterse 1991:104-119) en luisterproses (Chartier 1981:49-55) wek by hom assosiasies en 'n selektiewe ingesteldheid, tydens die prediking, wat van my intensie verskil; sodoende vind spontane leer plaas. Die opskrif 'spontaan/intensioneel' behoort dan ook in die piramide hierbo vanaf punt 8 tot punt 1 ingelees te word.

Die voorgestelde leermodel hierbo is 'n gelykstelling van Gagne se leervorme, waaraan bepaalde leerteorieë ten grondslag lê, en Maslow se behoeftepiramide. As motivering daarvoor dien die volgende:

- Oorlewing met kondisionering - Fisiologiese behoeftes oorheers die menslike bewussyn tot so mate dat S-R gedrag, as gedrag wat die minimum van energie in terme van kreatiewe denkprosesse impliseer, na vore tree. Leer vind derhalwe plaas deur te doen en te herhaal wat voorhande is of voorgeskryf word.

- Sekuriteit met versterking - 'n Ordelike gemeenskap bied aan die individu 'n fisiese verwysingsraamwerk waarmee uitgemaak kan word watter S-R gedrag belonend sal wees of die gepaste gevolge teweeg sal bring. Etlike insigte vanuit die ontwikkelingspsigologie, as die studie van die ontwikkelingsfases wat die mens van geboorte tot dood deurloop (Louw 1983:185-187; 1984:17-19), en die andragogie, as die studie van die leerproses eie aan volwassenes (Knowles 1978:27-29, 37, 48-51), is alhier noemenswaardig. Tussen sestien en vyf-entwintig jarige ouderdom is die mens by uitstek besig om homself as volwassene te probeer vestig (Lovell 1980:14-16; Louw 1983:23-24; 1984:372-395). Dit beteken dat hy as skoolverlater sy nuwe sosiale en beroepsrolle moet aanleer, overgesetsynde dat hy op soek is na verhoudings- en ekonomiese sekuriteit.

* Behorendheid met verbande en assosiusies - Die individu se gedrag binne sy groepsverbande bepaal grotendeels hoedanige vertroue, begrip en aanvaarding hy beleef. Die groep dien dus as versterker in die leerproses en help die individu om sy wêreld in terme van ooreenkomste en verskille tussen objekte en gebeure te kategoriseer. Vanuit 'n ontwikkelingspsigologiese en andragogiese oogpunt (Lovell 1980:16; Louw 1983:223-224; 1984:469), is dit juis die ouder- 
domsgroep vyf-en-twintig tot veertig wat moet aanleer om die magdom van kennis en ervaring vanuit vroeë volwassenheid te kanaliseer binne 'n reeds gevestigde netwerk van sosiale en beroepsverbande.

- Erkenning met kategorisering en konsepvorming - Erkenning binne die mens se vele referensiegroepe is noodsaaklik tot die ontdekking: 'Hier is ek nodig en bruikbaar!'. Hierdie behoeftevervulling fasiliteer die kognitiewe proses van situasie-insig, naamlik lees die situasie in terme van dit wat ons reeds weet maar die situasie kan ook ons gevestigde denkpatrone verander.

Weer eens kan ' $n$ mens die ontwikkelingspsigologie en andragogie by hierdie punt aanhoor (vgl Lovell 1980:17-18; Louw 1983:224-228; 1984:470, 519): tussen die ouderdom van veertig en sestig moet die mens die spesifieke probleme van verandering, in sy huislike sowel as werkskringe, oorbrug. Dit behels 'n herwaardering van norme, houdings en selfwaarde. Insiggewend dan dat die afgetredene hierdie herwaardering nog meer intens beleef, aangesien hy hom vroeër hoofsaaklik in terme van sy beroepsrol en -status waardeer het. Hierdie herwaardering behels primêr dat die afgetredene se behoefte hiërargies gesproke na die van behorendheid afskuif.

- Selfaktualisering met prinsiepvorming en probleemoplossing - Die mens se behoeftes tot potensiaalverwerkliking sluit juis by sy kognitiewe verwagting aan; 'n kognitiewe verwagting, gestimuleer deur geformuleerde doelwitte as gevolg van sy geïnterpreteerde lewensruimte, dat hierdie spesifieke gedrag hierdie spesifieke probleem sal oplos.

Die insigte van die ontwikkelingspsigologie en die andragogie het nie ten doel om ouderdom as determinant voor te hou nie (Knowles 1978:31; Louw 1984:5-19, 4647). Daarmee word bedoel dat ' $n$ bepaalde leerteorie, leervorm of leermotivering/ leerweerstand soos uiteengesit in die eie leermodel hierbo meer geskik of toepaslik sou wees maar nie uitsluitlik op net die kind of net die volwassene betrek behoort te word nie. Inteendeel, die leerproses is 'n dinamiese proses van leerteorie, leervorme en leermotivering/leerweerstande wat lewenslank by die mens voltrek word (Knox 1977:463-469). 'n Dinamiese proses wat afgestem is op selfaktualisering by beide kind en volwassene. Knowles (1978:9-10) stel in hierdie verband dat leer dus nooit as 'n problematiese opgaaf beskou moet word nie: vir die mens is die leerproses '...a way to be in the world.' Hiermee word bedoel (Knowles 1978:55-59):

* Die mens ondergaan 'n leerproses as groeiproses om van algehele afhanklikheid as baba tot selfgerigtheid as volwassene, te beweeg;

- Die mens is lewenslank aan 'n leerproses onderworpe, waartydens hy 'n sisteem van ervaringe opbou. As kind is ervaring dit wat met my gebeur; vir die volwassene is ervaring dit wat ek is. 
* Die leerproses impliseer 'n bepaalde leergereedheid by die mens, dit wil sê die aanleer van dit wat nodig is en nodig behoort te wees afhangende van die spesifieke ontwikkelingstake en sosiale rolle wat ek moet volvoer.

* Essensieël tot 'n optimale leerproses is die mens se leer-oriëntering. Waar dit subjekgesentreerd is, verloor die leergeleentheid sy relevansie. Die ideale leeroriëntering is probleemgesentreerd aangesien die mens dan die aangebore leergeleentheid kan benut om sy potensiaal tot probleemoplossing te ontdek en te ontwikkel. Sodoende kan hy met groter bevrediging sy rol in die gemeenskap vervul.

Die leerproses is derhalwe, in terme van die eie voorgestelde en geïntegreerde leermodel hierbo, 'n kognitiewe proses van selfaktualisering aan die hand van probleemoplossende gedragsverandering.

\section{GEVOLGTREKKINGS}

Die volgende afleidings met die oog op die prediking kan vanuit die voorgestelde en geïntegreerde leermodel gemaak word.

* Die leerproses se oorkoepelende einddoel is dat die mens kognitief en voluntatief tot selfaktualisering sal kom, dit wil sê dat hy probleemoplossend met sy omgewing in interaksie tree.

- Die leerproses is 'n komplekse en geîntegreerde proses van leerteorieë, leervorme en leermotivering en/of leerweerstande, dit wil sê leer is 'n dinamiese proses wat op meerdere vlakke voltrek word.

* Die leerproses verloop progressief, dit wil sê sommige leervorme sal meer geskik en toepaslik wees vir die kind as die volwassene en andersom. Die ontwikkelingsfases wat die mens deurloop moet dus in die leerproses verdiskonteer word sonder om van die ouderdom 'n determinant te maak.

* Die leerproses word deur allerlei faktore, intern en ekstern aan die mens, belemmer; sodanige leerweerstande kan by uitstek afgebreek word deurdat die mens se behoeftes as leermotivering benut word met die oog op die optimalisering van die leerproses.

* Die leerproses vertoon in sy veelvlakkigheid beide die fasette van spontane leer, deur middel van nabootsing en modellering, asook van intensionele leer, dit wil sê strukturering van 'n leersituasie toegespits op die totale mens. 
- Die leerproses koester ' $n$ holistiese benadering ten opsigte van die mens, dit wil sè die mens moet kognitief, affektief en konatief aangespreek word in die leerproses. Sodoende word leer beide die verkryging van insig en begrip asook 'n saak van gedragsverandering.

- Die leerproses sou derhalwe as langtermyn en dinamiese aktiwiteit van die totale mens nooit afgehandel wees nie.

- Die leerproses wys verskeie leervorme uit wat om spesifieke aandag vra vir die volgende leerfaktore:

** Leer vind deur middel van verbale en nie-verbale uitvoering, inoefening en herhaling plaas. Memorisering, die aanleer van gewoontes asook die voorskrywing en die voorlewing van gedrag is elementêre dog onvermydelike leervorme in die leerproses.

** Gedrag word gevestig indien die spesifieke optrede belonende gevolge het. Straf en beloning dien dus as dryfveer in die leerproses.

** Gedragsverandering geskied op grond van interne of eksterne dryfkragte wat om bevrediging vra. Die mens is dus affektief by die leerproses betrokke. Dit beteken dat sy eie behoeftes asook die lewensklimaat waarbinne hy beweeg opbouend of afbrekend meespreek in sy leerproses.

** Gedragsverandering behels die vorming en versterking van die gewenste gewoontes. Modellering as leervorm mag dus nooit in die leerproses afgemaak word nie.

* Leer vind ook deur middel van die mens se kognitiewe prosesse plaas. Formele kennisoordrag bly dus steeds 'n onontbeerlike leervorm in die leerproses.

* Die mens verander sy gedrag om sodoende sy omgewing te bemeester en te beheer. Die leerder verlang dus 'n werklikheidsrelevansie en 'n werklikheidsbetrokkenheid in sy leerproses.

** Die mens struktureer sy omgewing kognitief deur objekte en gebeure tot verbandhoudende kategorieë te prosesseer. Dit sou beteken dat die aangebode leerstof tydens die leerproses die leerder se reeds bestaande leerervarings sal moet verdiskonteer. 
** Leer vind plaas deurdat nuwe inligting of ervarings tot die geheelbeeld van bestaande denkpatrone geïntegreer word. Die leerder moet dus op hoogte gehou word van die betrokke doelstelling en doelwitte van elke spesifiek leersituasie. Sodoende word sy bestaande denkpatrone geaktiveer om nuwe kennis of ervaring te akkommodeer.

* Leer vind plaas deurdat nuwe inligting of ervarings geïnterpreteer word in die lig van reeds bestaande denkpatrone. Derhalwe sou daar tydens elke leersituasie geëvalueer moet word in watter opsig die aangebode leergeleentheid benut is.

\section{SLOTOPMERKING}

Die inleiding tot hierdie artikel het die volgende hipotese voorgehou: daar behoort bepaalde raakvlakke tussen 'leer' as fenomeen en die prediking van die kerk as wesenlik 'n leergebeure uitgewys te kan word. In die ondersoek wat na hierdie hipotese geloods is, is daar op metateoretiese vlak vanuit ander wetenskappe kennis geneem van die leerteorieë, leervorme, leerweerstande en leermotivering onderliggend tot die leerproses. Hierdie bepaalde sake is nie alleen geidentifiseer nie. Die gegewens is sodanig gekategoriseer sodat 'n geïntegreerde leermodel daargestel kon word: 'n leermodel wat poog om die voltrekking van die leerproses by die mens in sy totaliteit duidelik te maak. Vanuit hierdie leermodel is enkele leerteoretiese gevolgtrekkings geformuleer. Dit sal die taak van verdere studie wees om die homiletiese implikasies van sodanige gevolgtrekkings uit te spel. Sodoende word die hoop uitgespreek dat die kerk in prediking, soos gerugsteun deur alle ander terreine van die kerklike arbeid, opnuut die verantwoordelike taak kan volvoer om die lidmaat die betekenis van 'n lewe van eer en dankbaarheid voor God te 'leer'.

\section{Literatuurverwysings}

Barnard, A C 1981. Die erediens. Pretoria: NGKB.

Beukes, M J du P 1983. Kategese: 'n Handleiding vir kategete. Pretoria: Kital.

Bijlsma, R 1962. Kleine Catechetiek. 6de druk. Nijkerk: Callenbach.

Bolles, R C 1978. Learning theory. 2nd edition. New York: Holt, Rinehart \& Winston.

Bourne, L E (red) 1986. Cognitive processes. 2nd edition. Englewood Cliffs: Prentice-Hall.

Chartier, M R 1981. Preaching as communication: An interpersonal perspective. Nashville: Abingdon.

Dingemans, G D J 1986. In de leerschool van het geloof. Kampen: Kok. 
Dreyer, T F J 1989. 'n Poging tot 'n herdefinisie van die prediking binne die raamwerk van die Reformatoriese teologie. HTS 45/2, 350-369.

— 1991. Inleiding tot die Praktiese Teologie. Ongepubliseerde lesingaantekeninge, Universiteit van Pretoria.

Ellis, H C (red) 1979. Psychology of learning and memory. Monterey: Brooks/Cole.

Engelbrecht, B J 1989. 'n Vergelyking tussen die teologie van die Nederlandse Geloofsbelydenis en die Heidelbergse Kategismus. HTS 45/2, 626-664.

Engler, B 1985. Personality theories: An introduction. 2nd edition. Boston: Houghton Mifflin

Forster, J D \& Moran, G T 1985. Piaget and parables: The convergence of secular and scriptural views of learning. Joumal of Psychology and Theology 13/2, 97103.

Goldstein, H 1981. Social learning and change: $A$ cognitive approach to human senvices. New York: Tavistock.

Heyns, L M \& Pieterse, H J C 1990. A primer in Practical Theology. 1st edition. Pretoria: Gnosis.

Hill, W F 1985. Learning: A survey of psychological interpretations. 4th edition. New York: Harper and Row.

Hulse, S H (red) 1980. The psychology of learning. 5th edition. Johannesburg: McGraw-Hill.

Kerkwet en Bepalings van die Nederduitsch Hervormde Kerk van Afrika. 1986. Pretoria: NHW Pers.

Knowles, M 1978. The adult learner: A neglected species. 2nd edition. Houston: Gulf.

Knox, A B 1977. Adult development and learning. San Francisco: Jossey-Bass.

Koekemoer, J H 1991. Die betekenis van die kerklike dogma. HTS 47/1, 186-196.

Lee, J M 1985. The content of religious instruction. Birmingham: Religious Education Press.

Lefrancois, G R 1982. Psychological theories and human learning. 2nd edition. Monterey: Brooks/Cole.

Lieberman, D A 1990. Learning: Behaviour and cognition. Belmont: Wadsworth. Louw, D A (red) 1984. Inleiding tot die psigologie. Johannesburg: Mc Graw-Hill.

— 1984. Menslike ontwikkeling. Pretoria: Haum.

Lovell, R B 1980. Adult learning. London: Croom Helm.

Marx, M H (red) 1987. System and theories in psychology. New York: McGraw-Hill. Mitchell, C 1989. Die lerende aspek in die prediking - 'n kerugmaties-kommunikatiewe leermodel. Ongepubliseerde DDiv-proefskrif, Universiteit van Pretoria. 
Modgil, S C (red) 1987. B J Skinner: Consensus and controversy. London: Falmer.

Nel, M 1987. Teologiese perspektiewe op gemeentebou. Pretoria: NGKB.

Pieterse, H J C 1986. Verwoording en prediking. Pretoria: NGKB.

- 1988. Die Woord in die werklikheid: 'n Teologie van die prediking. Pretoria: NGKB.

- 1991. Gemeente en prediking. Halfway House: NGKB.

Richards, L O 1988. Christian education. Grand Rapids: Zondervan.

Swenson, L C 1980. Theories of learning: Traditional perspectives/contemporary developments. Belmont: Wadsworth.

Trevarthen, C 1986. Brain science and the human spirit. Zygon 21/2, 161-196. 